\title{
ATIVIDADES CIRCENSES: CARACTERIZAÇÃO DAS MODALIDADES, CAPACIDADES BIOMOTORAS, METABOLISMO ENERGÉTICO E IMPLICAÇÕES PRÁTICAS
}

Raquel de Brito Sacco

Tiago Volpi Braz

\section{Resumo}

As atividades encontradas no âmbito circense causam encantamento aos espectadores e aos praticantes devido à sua complexidade. Ao considerar o objetivo do circo de encantar o público e suas características contemporâneas, analisou-se as principais semelhanças motoras entre as modalidades circenses que se agrupam de acordo com as características: acrobacias, aéreos, malabarismo e equilibrismo. No sentido de desvendar tal magia, diante do presente estudo analítico de revisão pesquisou-se os fatores:

i) metabólicos,

ii) fisiológicos bem como a

iii) dinâmica de atuação da musculatura esquelética e a

iv) capacidade biomotora predominante nestas práticas. A partir desta análise, sugere-se meios para compor os treinamentos de um artista circense que pratica tais modalidades, bem como considerar a força como a capacidade biomotora determinante e quando predominante para a realização das modalidades circenses analisadas e o metabolismo anaeróbio como a via principal para gerar energia. A resistência de força encontrou-se presente e necessária nas modalidades devido a repetições constantes dos movimentos nos treinamentos bem como em cada apresentação circense e em um conjunto destas apresentações, ou seja, em um espetáculo em si. Por fim, sugere-se futuros estudos enfocando os princípios de treinamento bem como o aspecto nutricional e outras vertentes biológicas aplicados em artistas circenses no intuito da melhora da performance neste setor.

\section{PalavrasChave}

Modalidades circenses; Capacidades biomotoras; Metabolismo energético; Meios de treinamento.

\section{CIRCUS ACTIVITIES: THE CHARACTERISTICS OF MODALITIES, HUMAN CAPACITIES, ENERGY METABOLISM AND PRACTICAL IMPLICATIONS}

Raquel de Brito Sacco

Tiago Volpi Braz

\begin{abstract}
The activities found in the circus cause delight to the viewers and practitioners due to its complexity. When considering the objective of the circus to enchant the public and the type of contemporary circus to get a good technique, it was analyzed the circus acrobatics modalities, aerial, juggling and biomechanically balance. In order to discover such magic, some factors were analytical reviewed such as:

i) metabolic,

ii) physiological as well as

iii) the dynamic performance of skeletal muscles and

iv) the biomotor ability predominant. Through this analysis, it was possible to contribute for the involved ones in this area on composing the training of a circus artist who practices such modalities. Based on
\end{abstract}


these notes, it was considered the driving force as the ability biomotor and predominant factor for the implementation of procedures and circus anaerobic metabolism as the major route for energy in certain activities. The resistance force is present and necessary in terms due to constant repetition of movements in training and presentations. Finally, we suggest that future studies focusing on the principles of training and the nutritional aspect and other aspects of applied biological circus athletes in order of improvement in human performance.

\section{Key-Words}

Circus modalities; Biomotoras capacities; Energy metabolism; Ways of training. 


\section{INTRODUÇÃO}

Artes circenses são expressões humanas que há relação com o ato esportivo, podendo elas ser de qualquer forma, desde que seja considerada como algo encantador. Circo é o lugar que expressa essas artes, lugar que encontramos a lona, o picadeiro e todos os materiais que nele há (TORRES, 1998).

Para complementar, o Dicionário Priberam da Língua Portuguesa (2008) traduz a arte por manha, habilidade ou astúcia, e circo, como recinto circular e coberto para espetáculos, ou arena, círculo. Quando um se relaciona ao outro temos as "artes circenses" que por sua vez, podem ser chamadas por "atividades circenses".

As artes circenses realizadas num espetáculo de circo devem obedecer ao objetivo de entreter o público, deixando-os encantados, maravilhados e impressionados, por meio de movimentos que expressam "... medo, maravilhamento, temor, apreensão, satisfação e principalmente o sentimento de liberdade..." (DUPRAT, p.19, 2007).

No intuito de obter o encantamento do público, os artistas circenses devem desenvolver um processo de preparação específica, ponderadas sobre diferentes perspectivas. A partir disto, torna-se necessário entender que estes artistas necessitam alcançar determinada performance para terem êxito em seus objetivos, justificando a admiração e entretenimento do público presente nas apresentações. De fato, alguns aspectos devem ser considerados para o alcance de tais objetivos, como o

i) pedagógico: respectivo ao ensino-aprendizagem das técnicas de execução dos movimentos circenses envolvendo o processo de aquisição gradativo de habilidades motoras;

ii) o filosófico: atinge o encantamento, a magia e os aspectos cognitivos da atividade circense, e

iii) o biológico: referente ao conhecimento do comportamento biológico do indivíduo mediante a atividade que está se propondo a realizar, como fatores metabólicos, fisiológicos, dinâmica da musculatura no trabalho, capacidades biomotoras predominantes.

Isto corrobora com o conceito de performance humana apresentado por Alves et al. (2004), correspondente à integridade do ser humano sendo priorizado a segurança, ao propor capacitá-lo para atingir o máximo que lhe é concebido, de acordo com suas respectivas limitações comparadas a si mesmo no decorrer das diferentes fases da vida. A performance humana pode se resumir como a própria vida no 
$\overline{\text { Universo, em harmonia com o mesmo, que respeita a individualidade em variadas situações da existência }}$ de cada indivíduo (PELLEGRINOTTI, 2004).

Ao se deparar com estes conceitos, tudo o que é arte e encanta os espectadores, pode ser apresentado num espetáculo de circo. Por este fato, são inúmeras as modalidades apresentadas que podem e devem ser inventadas e transformadas. Essas progridem ao longo do tempo ao atender a demanda tecnológica e moderna, aderidas e oferecidas à sociedade. Baroni (2006) afirma que os artistas circenses têm o prazer em presenciar uma emocionante e constante mutação e transformação dos movimentos de características não convencionais e habituais das atividades do circo. Neste sentido, as práticas circenses podem ser as mais variadas possíveis, das quais serão destacadas as de características aéreas, acrobáticas, malabarísticas e de equilíbrio.

Alguns estudos têm sido realizados focando a investigação das atividades circenses. Duprat (2007) discute as possibilidades e perspectivas das atividades circenses na Educação Física Escolar. Bortoleto e Calça (2007a; 2007b) oferecem informações sobre o tecido e o trapézio ao descreverem o material, as formas de fixar o aparelho, os importantes fatores de segurança e também uma breve história de cada modalidade. Baroni (2006) analisa o circo e seu entorno da forma que ele era e é, suas modificações, seus valores e seus princípios dentro e fora da lona. Particularmente, quanto aos aspectos biológicos, Bellotto (2008) cita importantes informações sobre a nutrição para os praticantes de circo revisando brevemente as vias metabólicas, os tipos de substratos existentes e necessários como também alguns exemplos de cardápio e a forma para se calcular a caloria a ser ingerida durante o dia. Nesta linha, Tomaz, Motta e Souza (2009) buscaram analisar os parâmetros hemodinâmicos e antropométricos entre praticantes de tecido aéreo e escalada indoor.

Porém, ainda são escassos os estudos que abordem os aspectos biológicos da atividade circense, o que justifica a necessidade de referenciais teóricos discutindo tais perspectivas. A partir disto, o presente estudo tem como objetivo entender os aspectos biológicos da atividade circense, precisamente sobre os fatores metabólicos, fisiológicos, dinâmica de atuação da musculatura, bem como as capacidades biomotoras determinantes para a prática da atividade. Em conseqüência, o estudo foi estruturado da seguinte forma:

i) metodologia,

ii) questões histórico-filosóficas das atividades circenses, 
iii) modalidades circenses,

iv) capacidades biomotoras e metabolismo energético das modalidades circenses,

v) exercícios como meio de treinamento das atividades circenses e vi) considerações finais.

\section{METODOLOGIA}

O presente estudo trata-se de uma pesquisa analítica de revisão de literatura, já que envolve o estudo e a avaliação, em profundidade, das informações disponíveis na tentativa de explicar fenômenos complexos e a avaliação crítica de pesquisas recorrentes sobre determinado tópico (THOMAS; NELSON, SILVERMAN, 2007).

Os instrumentos de pesquisa foram

i) artigos publicados em periódicos indexados no Qualis CAPES,

ii) dissertações e teses,

iii) livros registrados no International Standard Book Number (ISSN) e

iv) websites correspondentes a temática do estudo. Os artigos foram obtidos no Portal Capes por meio das bases de dados EBSCO HOST, Wilson Web, SCOPUS, além da Scientific Electronic Library Online (SCIELO) e Google Acadêmico. Os livros e teses foram consultados nos acervos da biblioteca da UNIMEP (Universidade Metodista de Piracicaba - Campus Taquaral) e UNICAMP (Universidade Estadual de Campinas - Faculdade de Educação Física - Campinas/SP e Faculdade de Ciências do Desporto - Limeira/SP).

Foram utilizadas palavras-chave como circo, atividades circenses, artes circenses, acrobacia, tecido aéreo, trapézio circense, malabarismo, circus, circus activity aerial silk, static trapeze, juggling, acrobatics, capacidade motora, capacidade física, capacidade biomotora, força, força dinâmica e estática, metabolismo energético, via energética, contração muscular, meios de treinamento.

Não houve restrição de período para encontrar estudos relacionados à área circense, já que constatou-se que o número de pesquisas sobre a temática é reduzida. Quanto aos referenciais correspondentes a área biológica determinou-se pesquisas a partir do ano 2000. Nisto, foram utilizadas 44 referências, das quais 15 artigos, 3 teses e dissertações, 2 resumos de congresso, 1 fórum internacional, 22 livros e 1 website. 


\section{QUESTÕES HISTÓRICO-FILOSÓFICAS DAS ATIVIDADES CIRCENSES}

Duprat (2007) menciona que o termo "circo moderno" representa a modernidade da produção mecanizada que, até o momento da revolução industrial a produção era artesanal e nesta época de mudança o circo constituiu-se como espetáculo. Outro termo utilizado para o mesmo tipo de circo é o "tradicional", pelo fato de ser apresentado por grupo fechado e enraizado de pessoas que se desenvolveram da arte das feiras e ruas, na qual o conhecimento circense era obtido através da transmissão oral (DUPRAT, 2007). É reconhecido também como "circo família” (BARONI, 2006), pois o conhecimento e os costumes destes artistas são passados de geração em geração desde como montar a tenda até o mais fantástico número circense, seguindo a tradição do circo e da família. Por fim, se classifica como "circo de grandes dimensões" ou "de atrações" que se compõe da antiga arte circense que além dos malabaristas, acróbatas e entre outros artistas humanos, animais amestrados também fazem parte do elenco (MAGNANI, 1998 apud BARONI, 2006). Portanto, o circo tradicional pode ou não ter animais.

Os "mestres" do circo tradicional são pessoas mais velhas e experientes que ensinam e transmitem os saberes circenses para crianças e jovens (SILVA, 1996), diferente do circo atual, no qual professores especializados em diferentes artes, inclusive nas circenses, ensinam esta prática e filosofia. Esses profissionais contribuíram para a transformação do formato estético do circo e de novas técnicas inseridas nele (JACOB, 1992 apud DUPRAT, BORTOLETO, 2007) no sentido de transmitir o conhecimento às pessoas interessadas, em locais como escolas especializadas. Devido a estas transformações, deu-se início ao "circo novo". Este tipo de circo segue tudo aquilo que há de mais novo na sociedade: desde o saber circense refinado até a alta tecnologia dos dias de hoje.

Outra forma de se referir a este tipo de circo é por "circo contemporâneo", que significa o circo no tempo atual. Este significado permite entender que o circo sempre foi contemporâneo de acordo com o conhecimento e saberes de cada época, sempre buscando o que há de mais novo (DUPRAT, 2007). O termo contemporâneo é relativo por se referir aos diferentes tipos de circo, ao dialogar com a sociedade e com as expressões corporais do momento.

No entanto, o circo tradicional possui sua entidade própria por saberes enraizados na tradição e elaborados a milhares de anos por uma cultura única e fechada, apresentados geralmente em locais livres ocupando uma arena coberta por tenda, lona ou capa devido a falta de espaços adequados como anfiteatros e similares. Por outro lado, as primeiras visões do circo novo foram destacadas pela junção da 
$\overline{\text { arte do teatro e do circo, possuindo em seu âmbito antecedentes ou não de familiares circenses, porém }}$ com rico valor artístico (DUPRAT, BORTOLETO, 2007), no qual os mais variados públicos da atualidade praticam essa arte em academias, escolas, clubes e ONGs (DUPRAT, 2007) com diversas finalidades como lazer-recreação, fins educativos e sociais (BORTOLETO, MACHADO, 2003).

No contexto físico, social, psicológico, profissional e pessoal do indivíduo, o circo é uma versão moderna de entretenimento (DE GÁSPARI, SCHWARTZ, 2006) e da prática esportiva por conter riqueza motriz e social e pela sua mesma importância de outras práticas tradicionais (jogos, esportes, danças, etc) (BORTOLETO, 2006) oferecendo relevante contribuição para a sociedade ao formar cidadãos conhecedores das diferentes artes corporais brasileiras (GALLARDO, GUTIÉRREZ, 2008).

O "circo do homem" (por ter somente humanos nas performances) prioriza atletas de alto rendimento das diversas sub-modalidades da ginástica (DUPRAT, 2007) adotando a motricidade específica dos esportes, pois contribuem para uma técnica perfeita e extraordinária (BARONI, 2006). Os esportes de alto rendimento e este tipo de circo visam a alta performance, causando uma relação entre eles. Sendo que, nas ginásticas os atletas apresentam movimentos pré-determinados sujeitos a julgamentos e no circo os artistas se movimentam livremente com a preocupação de entreter o público (SILVEIRA, SILVA, CASTRO, 2008).

Pode-se visualizar nos movimentos circenses contemporâneos uma necessidade da estética do corpo forte, ágil e flexível assim como nos esportes de alto nível, observando em comum a disciplina e a técnica apurada (ROSA, 2003 apud BARONI, 2006). Tal fato permitiria utilizar o termo "atletas circenses" além de "artistas circenses", pois mescla algumas características dos esportes de alto rendimento a arte do circo, porém, o circo não deve deixar de ser visto como arte, graça, cultura e história, que expressa sentimentos emocionando a todos os espectadores.

Devido a isso, profissionais e pesquisadores da arte circense devem se atentar para que essa área encantadora aos olhos de todos não se torne sujeito a julgamentos e a regras, prejudicando a liberdade de criar e a magia circense. Silveira, Silva e Castro (2008) afirmam que coreógrafos do circo novo criam as coreografias e os atletas obedecem. Isso pode interferir na criatividade e na oportunidade de serem artistas que, não somente reproduzem, mas que criam a arte que compõe o circo, desde a estrutura física até o mais extraordinário movimento. 
Os autores acima ainda citam que a visão de corpo do circo novo está muito próxima da visão das ginásticas de competição no sentido de buscar uma aceitação e legitimação social. Por outro lado, essa mudança que o circo novo trouxe, oportuna outras pessoas que possuem o talento circense a entrar para a arte do circo. Assim, a valorização, o aperfeiçoamento, o interesse e novas criações crescerão nesta área, proporcionando o prazer e o encantamento às pessoas espectadoras e praticantes.

\section{MODALIDADES CIRCENSES}

O circo pode ser classificado em práticas combinadas que englobam várias modalidades distribuídas em diferentes grupos (ou famílias), como as acrobacias, aéreos, malabarismo e equilibrismo, oferecendo aos praticantes um repertório motor variado, pela sua complexidade. É necessário que as interpretações psicológicas e fisiológicas sejam feitas de acordo com a especificidade de cada modalidade envolvida devido à diferenciação das mesmas e também da intensidade relacionada a cada uma delas (BOMPA, 2002).

Neste âmbito, algumas pesquisas têm proposto classificações das modalidades circenses. Duprat (2007) destaca três classificações com diferentes direcionamentos: i) a classificação adotada pelo CNAC da França, estruturada para o desenvolvimento de artistas profissionais; ii) outra baseada no tamanho e utilização ou não de materiais para melhor aplicação na educação física escolar, bem como iii) as modalidades advindas de determinadas unidades didático-pedagógicas como tema organizador que engloba gestos e movimentos corporais gerais similares para facilitar o professor e o aprendiz no desenvolvimento teórico-prático dos exercícios. Para cumprir o objetivo biológico proposto no presente estudo, foi adaptada a última classificação citada, como demonstra a Tabela 1. 
Tabela 1- Classificação do grupo de modalidades circenses pela semelhança do gesto desportivo, especificidade e modalidade.

\begin{tabular}{|c|c|c|}
\hline $\begin{array}{c}\text { Semelhança do } \\
\text { Gesto } \\
\text { Desportivo }\end{array}$ & Especificidade & Modalidades Circenses \\
\hline & Solo & De Chão (solo). \\
\hline \multirow{3}{*}{ Acrobacias } & Equilíbrios & Paradismo (chão e mão-jotas); \\
\hline & Acrobáticos & Poses Acrobáticas em Dupla, Trio e Grupo. \\
\hline & Trampolinismo & Trampolim Acrobático; Mini-tramp; Maca Russa. \\
\hline Aéreos & Aéreos & $\begin{array}{l}\text { Trapézio Casting; Tecido Marinho; Lira; Corda } \\
\text { Indiana; etc. }\end{array}$ \\
\hline \multirow{4}{*}{ Malabarismo } & De Lançamento & $\begin{array}{l}\text { Bolas; Lenços; Aros; Claves, Bolas de Rebote; Tochas } \\
\text { de Fogo, etc. }\end{array}$ \\
\hline & $\begin{array}{l}\text { De Equilíbrio } \\
\text { Dinâmico }\end{array}$ & Bolas; Vassouras; etc. \\
\hline & Giroscópicos & $\begin{array}{l}\text { Pratos; Diabolô; Iô-iô; Swing; Flag; Devil e Flower } \\
\text { Stick. }\end{array}$ \\
\hline & De Contato & $\begin{array}{l}\text { Bola de Contato; Agrupamentos de Bolas (Rolling) e } \\
\text { Chapéus. }\end{array}$ \\
\hline \multirow{2}{*}{ Mágicas } & $\begin{array}{l}\text { Manipulações de } \\
\text { Objetos }\end{array}$ & Baralhos e Cartas; Moedas; etc. \\
\hline & $\begin{array}{l}\text { Manipulações de } \\
\text { Pessoas }\end{array}$ & $\begin{array}{l}\text { Corpo Cortado pela Metade; } \\
\text { Explosões, Desaparecimentos; etc. }\end{array}$ \\
\hline Equilibrismo & Funambulescos & $\begin{array}{l}\text { Perna de Pau; Monociclo; Arame; } \\
\text { Corda Bamba; Rolo Americano (rola-rola); etc. }\end{array}$ \\
\hline $\begin{array}{l}\text { Expressão } \\
\text { Corporal }\end{array}$ & Expressão Corporal & $\begin{array}{l}\text { Elementos das Artes Cênicas; } \\
\text { Dança; Mímica; Música. }\end{array}$ \\
\hline Palhaço & Artes em Geral & Artes Cênicas de Diferentes Técnicas e Estilos. \\
\hline
\end{tabular}


$\overline{\text { As ações motoras realizadas por um artista circense compõem-se de vários movimentos articulados, }}$ porém as ações motoras que contenham semelhanças em seu contexto de determinado grupo de modalidades serão destacadas nos próximos subtítulos de forma isolada (ZAKHAROV, GOMES, 2003), divididas em

i) acrobacias,

ii) aéreos,

iii) malabarismo e

iv) equilibrismo.

\section{ACROBACIAS}

As infinitas variações de saltos entre os três eixos de rotação corporal (longitudinal, transversal e sagital) (BORTOLETO, 2003a) ou, movimentos de vôos, rotações e inversões (BORTOLETO, ESCALANTE, 2006a) caracterizam as acrobacias circenses.

Para conceituar acrobacia, entendida por habilidade antinatural não advinda de uma herança genética, é necessário basear-se nas ginásticas (artística, rítmica, acrobática, trampolim e geral), já que o domínio corporal, a base motora e os princípios que violam as leis da física encontram-se em comum entre essas modalidades esportivas e as existentes no circo (no caso, as do grupo de acrobacia) (BORTOLETO, 2008a). Porém, para o mesmo autor, o significado próprio deste termo não permite um conceito único ou um entendimento completo sobre o que realmente é este fenômeno.

Nesta perspectiva, Silveira, Silva e Castro (2008) relatam que o circo e as ginásticas têm um mesmo padrão científico e técnico, tendo em comum a educação corporal, sendo o caráter competitivo das ginásticas e a liberdade de expressão do circo, a principal diferença entre eles.

Essa relação íntima possibilita explorar os estudos existentes sobre as ginásticas para complementar as pesquisas circenses. Portanto, de acordo com Bortoleto (2003a), na ginástica artística encontra-se o solo e a trave, na ginástica acrobática os lançamentos e saltos, enquanto no circo, as modalidades acrobáticas. Na ginástica rítmica, o lançamento e a manipulação de objetos são inerentes, no circo também, porém na execução das modalidades de malabarismo. Na ginástica em geral existem diferentes espaços como o trampolim e outros diferentes aparelhos, assim como no circo, onde encontra-se o tecido liso, o trapézio fixo, entre outros.

Conexões: revista da Faculdade de Educação Física da UNICAMP, Campinas, v. 8, n. 1, p. 130-161, jan./abr. 137 2010. ISSN: 1983-930 
Neste sentido, por meio de relatos de Rego, Reis e Oliveira (2007), comprova-se que os exercícios da ginástica artística e os da ginástica acrobática utilizam excessivamente os membros superiores. Quanto a utilização de membros inferiores destacaram que é elevada no trampolim, pelos altos saltos que os atletas atingem tendo que aumentar a eficiência desses membros na recepção dos exercícios. A ginástica rítmica explora a flexibilidade em amplitudes extremas utilizando a força. A artística está sujeita a diferentes recepções em superfícies variadas de acordo com o aparelho. $\mathrm{Na}$ acrobática, os saltos são realizados em menores alturas e freqüência.

Portanto, nas atividades do grupo de acrobacias circenses de acordo com sua variedade de movimentos ocorre de forma semelhante, atribuindo alguns parâmetros indiretos a prática acrobática do circo, auxiliando este conhecimento aos preparadores físicos circenses.

As acrobacias (de solo principalmente) costumam ser apresentadas em série, ou seja, em sequência de movimentos acrobáticos interligados, cujos exercícios são ensaiados com antecedência (prédeterminados) para sua realização (PARLEBAS, 2001 apud BORTOLETO, 2008a).

O domínio corporal, ou seja, o controle do corpo no espaço e no tempo advindo da acrobacia é relevante, por isso é considerada como base da preparação corporal dos atletas circenses. Bortoleto (2008a) explica que é pela força, flexibilidade, postura, coragem, dentre outras qualidades treinadas incansáveis e meticulosamente que a acrobacia se torna um papel importante no âmbito circense. De forma dinâmica e prática tais movimentos ensinam e atribuem ao repertório motor dos atletas dando subsídios para caírem de forma correta tanto nas próprias acrobacias como também em outras atividades circenses, se protegendo de possíveis acidentes.

\section{AÉREOS}

Os movimentos realizados nas modalidades aéreas são condizentes à estrutura de cada aparelho, que permite ao artista realizar diversas variações corporais com o destaque da qualidade e destreza dos movimentos, porém necessitam de uma segurança garantida aos praticantes (BORTOLETO, CALÇA, 2007c).

Dos aéreos, o tecido acrobático é considerado o mais fácil de todos para aprendizagem, pois ele se adere e se adapta ao corpo do praticante de acordo com suas características (BORTOLETO, CALÇA, 2007a), ao 
$\overline{\text { contrário de outros materiais, como o trapézio e a lira, por exemplo, que o praticante se adapta ao }}$ aparelho, exigindo mais força e flexibilidade.

Porém, isso pode ser diferente para algumas pessoas que têm força e flexibilidade apuradas e que consigam melhor realizar outras práticas aéreas do que o tecido, que por sua vez, exige da coordenação motora fina ao enrolar e desenrolar o tecido em todas as partes do corpo, fazendo isso, muitas vezes, na posição invertida, o que necessita da noção temporal e espacial junto a essa habilidade.

Não há regras para as práticas aéreas assim como todas as outras modalidades circenses, porém existe a necessidade de criar e inovar, por isso, até o momento encontra-se quatro modalidades diferentes que utiliza-se o tecido, sete do trapézio, três da corda e da lira em seus diferentes tipos de formato. Assim, varia-se a fixação, os truques, as quedas, os movimentos, as travas e as figuras entre elas. O tecido liso é a modalidade mais comum e conhecida, sua aplicação é mais fácil devido a sua fixação e execução, pois para esse último fator, necessita de uma pessoa somente. Já o double tecido, é uma modalidade realizada em duas pessoas no tecido liso e os movimentos podem ser os mesmos realizados pelos dois (um em cada parte do tecido ou na mesma parte) ou em forma de portagem, no qual o mais forte segura e dá base para o mais leve e flexível. O tecido marinho é uma das modalidades de tecido que se difere das outras na sua amarração, onde é preso pelas duas extremidades numa distância de 2 a 3 metros formando o desenho de uma balança. Os movimentos são realizados no meio do tecido, parecida com outra modalidade circense, a corda marinha. Ao última modalidade aérea de utilização do tecido a ser citada, é o tecido ao vôo, que é semelhante à modalidade faixa circense, e sua fixação é parecida com a do tecido liso. Para o artista realizar as manobras na extremidade do tecido, a altura do mesmo é variada em relação ao solo, o que aumenta as possibilidades de truques ao serem tracionadas pelo moitão (manual) ou pelo guincho (automático) (BORTOLETO, CALÇA, 2007a). Os movimentos realizados neste aparelho são variados, já que sua estrutura permite inovar amarrações assim como a forma de utilização de acordo com a idéia do artista (BORTOLETO, CALÇA, 2007a).

Calça e Bortoleto (2008) descrevem pedagogicamente algumas subidas, figuras, travas e quedas básicas para praticar o tecido circense. Por meio das referências bibliográficas, percebe-se determinadas semelhanças no gesto motor em vários segmentos corporais destes movimentos, dentre eles, os braços e as pernas que sustentam o peso corporal do praticante. Porém, no momento em que os membros inferiores se movimentam para a preparação de alguma figura, queda ou trava, é exercido com mais facilidade devido ao tamanho do grupo muscular bem como sua quantidade e tipo de fibras existentes Conexões: revista da Faculdade de Educação Física da UNICAMP, Campinas, v. 8, n. 1, p. 130-161, jan./abr. 139 2010. ISSN: $1983-930$ 
$\overline{\text { (BOSCO, 2007). Por outro lado, na posição invertida, a sustentação do peso corporal do praticante se dá }}$ pela força dos braços ou por alguma amarra, normalmente com o tecido envolto da cintura ou pernas.

Quanto ao trapézio, sua estrutura consiste numa barra de ferro de aproximadamente $70 \mathrm{~cm}$ suspensa por duas ou mais cordas de cabos de aço revestidas e fixadas com uma abertura um pouco maior que a da barra, desenhando a figura geométrica de um trapézio, para dar maior estabilidade durante a execução dos truques. Segundo relatos de Bortoleto e Calça (2007b), a estrutura é compatível com a modalidade do trapézio, de forma que em algumas há contrapesos nas extremidades da barra para aumentar a estabilidade do trapézio, porém, isso ocorre com mais frequência no trapézio de balanço, no qual movimentos, figuras, truques e quedas utilizados também no trapézio fixo, dentre outros exercícios mais complexos, são realizados quando o trapézio está em balanço, tal como uma balança de parque.

O porto ou portor é a principal característica do doble trapézio (também realizado no trapézio de balanço). Tal truque é realizado por dois indivíduos: o aparador é o mais forte e pesado para permitir levar, lançar, agarrar e dirigir o volante, que por sua vez é o mais leve e ágil da dupla para executar movimentos orientados pelo aparador. Enquanto, a condição principal do trapézio múltiplo é ter duas (duplo) ou mais pessoas (triplo, quádruplo...) realizando movimentos individuais ou sincronizados, diferente do trapézio de vôo, que é necessário um trapézio simples e outro para o portô, além da banquilha (onde partem e chegam os artistas que balançam e voam). Por outro lado, o trapézio washington ou wasinton possui um suporte de prancha de madeira na qual são realizadas manobras de equilíbrio e apoios invertidos com a utilização ou não do rola-rola e/ou tanquinho (utilizado como apoio de mãos na realização da parada de mãos, esquadros, entre outras destrezas) geralmente com o trapézio em balanço ou em giros. E, por último, o trapézio castin ou casting, estruturado por uma aparelhagem em metal suspensa onde o portor apóia os pés e é preso no abdômem por um cinturão dando liberdade para manipular o volante que realiza vários movimentos. Esta modalidade de trapézio permite acrescentar o trapézio de vôo, e consequentemente, uma base intermediária (BORTOLETO, CALÇA, 2007b).

A lira pode ser considerada uma variação de trapézio, em sua forma redonda, quadrada, estrelada ou em gota onde sua principal característica é o giro, que acessórios distorcedores o fazem. Existem também suportes para parada de mãos ou cabeça acoplados na lira assim como no trapézio washington, e estafas para prender as mãos, pés e pescoço do artista assim como na corda indiana que, além disso, giram com auxílio de outra pessoa em torno de si e da corda realizando figuras. Na corda lisa, realiza-se semelhantes 
travas, quedas, é suspensa pelas duas extremidades permitindo o artista realizar evoluções parecidas com o trapézio de balanço quando feitos no centro da corda (BORTOLETO e CALÇA, 2007c).

No propósito de sintetizar as classificações das modalidades aéreas, propõe-se a Tabela 2.

Tabela 2- Classificação das modalidades aéreas

\begin{tabular}{cc}
\hline $\begin{array}{c}\text { Aparelhos de Característica } \\
\text { Aérea }\end{array}$ & Modalidades Circenses \\
\hline Tecido & Tecido liso; Tecido marinho; Doble tecido; Tecido ao vôo. \\
& $\begin{array}{c}\text { Trapézio fixo; Trapézio de balanço; Doble trapézio; Trapézio } \\
\text { múltiplo; }\end{array}$ \\
Trapézio & Trapézio de vôo; Trapézio Washington; Trapézio Castin. \\
& Corda lisa; Corda indiana; Corda marinha. \\
Corda & Forma de gota, estrela, quadrada e redonda. \\
\hline Lira &
\end{tabular}

\section{MALABARISMO}

O malabarismo se agrupa em quatro categorias distintas: i) malabarismo de lançamento, ii) malabarismo de equilíbrio dinâmico, iii) malabarismos giroscópicos e, por fim, iv) malabarismos de contato (DE BLAS, 2000 apud DUPRAT, BORTOLETO, 2008), de forma que, a principal característica deste grupo de modalidade é manipular diferentes objetos.

Na primeira categoria, os malabaristas lançam e recepcionam os objetos com uma, duas ou mais mãos (no caso de mais de uma pessoa), desenhando uma figura com os objetos lançados, podendo estes ser bolas, aros, claves, lenços, entre outros. Existem vários truques e formas de realizar esta forma de malabarismo, como passar a bola por trás das costas, debaixo da perna, com os antebraços cruzados, entre outras diversas maneiras. O ritmo para lançar, ou seja, a duração de tempo desde que a bola é lançada ao ar até ela ser recolhida pode ser descrito por siteswap, onde números representam determinados ritmos facilitando o aprendizado, a descoberta e a transmissão de truques (DUPRAT, BORTOLETO, 2008). 
A segunda classificação, segundo sua própria denominação, mantém um ou mais objetos em equilíbrio dinâmico instável e marginal (DE BLAS, 2000 apud DUPRAT, BORTOLETO, 2008). O primeiro possui um ponto de contato somente, assim como o equilíbrio de uma vassoura na testa por exemplo, e o segundo, utiliza uma linha reta como apoio para determinado objeto, como é o exemplo do equilíbrio de uma bola entre a testa e o nariz. Na terceira classificação o objeto gira sobre si mesmo numa elevada velocidade, mantendo-se em rotação sobre uma referência, como os pratos, o diabolô, o iô-iô (DUPRAT, BORTOLETO, 2008) o devil stick, flower stick e o swing. A quarta classificação caracteriza o objeto em contato com alguma parte do corpo do praticante causando a impressão de serem um só. Realiza-se também lançamentos e giros com um ou mais objetos.

Por utilizar os dois lados do corpo atravessando a linha sagital, o malabarismo estimula os dois hemisférios cerebrais que atua na aprendizagem motora de forma enriquecedora. Desenvolve também a capacidade de reação e raciocínio promovendo um aumento da concentração e atenção, assim como um aumento da capacidade da visão focal e ambiental, além de ser comprovado mudanças na estrutura cerebral e o envolvimento de habilidades cognitivas e percepção espacial complexa devido a prática malabarística (DENNISON (1995), HAWK, 2001, FINNIGAN, 2001, DRAGANSKI, 2004, TRUZZI, 1979 apud MANSUR et al., 2007).

\section{EQUILIBRISMO}

A característica principal para se determinar modalidades de equilibrismo é o indivíduo buscar o equilíbrio por meio de situações que promovem o desequilíbrio devido à instabilidade das superfícies dos materiais utilizados (BORTOLETO, LOPES, MORALES, 2008). Essas modalidades circenses podem ser combinadas com acrobacias, malabarismo e hope skipping (saltar corda ou laço) (BORTOLETO, 2008c) dependendo da estrutura do material de cada modalidade para permitir tais truques. Elas dependem principalmente da atuação do sistema nervoso central e neuromuscular de membros inferiores, pois estes servem como ponto de apoio, já que os materiais de equilibrismo não oferecem. Movimento rápido para subir, semi-flexão de joelhos e a pressão da superfície da planta dos pés para manter o equilíbrio em pé, apoiar-se em um dos pés para a movimentação do outro como também para a modificação da posição do corpo, agachamentos e saltos (BORTOLETO, 2004) são comumente executados para a atuação eficaz destes materiais.

Conexões: revista da Faculdade de Educação Física da UNICAMP, Campinas, v. 8, n. 1, p. 130-161, jan./abr. 142 2010. ISSN: $1983-930$ 
No rola-bola, esses movimentos e outros possíveis são realizados por meio do deslizamento de uma prancha sobre um cilindro, prevalecendo a superfície instável por meio de movimentos de equilíbrio dinâmico (BORTOLETO, 2008b). Enquanto a perna de pau altera a estatura normal do praticante, modificando também os aspectos mecânicos e sensitivos ao ficar em torno de $50 \mathrm{~cm}$ a mais do que a altura habitual. Pode se apresentar em vários tipos, formas, alturas e materiais de acordo com o objetivo, disponibilidade financeira, entre outras situações. O desequilíbrio constante nesta prática é devido ao apoio no solo de tamanho semelhante a uma décima parte de um pé de adulto, sendo difícil manter a posição estática, particularidade esta, de atletas com treinabilidade desenvolvida. A perna de pau considerada como convencional é a qual exerce as pernas e os pés como apoio de forma fixa impossibilitando o abandono do material. Outro tipo de aparelho é com o apoio nas mãos tendo os pés e as pernas livres, o que permite o praticante deixar a perna de pau a qualquer momento (BORTOLETO, 2003c).

Já o monociclo permite o praticante realizar os movimentos sobrepondo-se a instabilidade de uma roda em apoio ao chão. Sua estrutura consiste em uma roda, pé de vela para fixar os pedais, garfo ou estrutura de metal e um banco de acento. Existem 5 modalidades de monociclo que se diferenciam pelos obstáculos a ser enfrentados como também pela estrutura, modificando o pneu, garfo e banco de acento de acordo com sua especificidade. Entre eles estão: monociclo trial, monociclo mountain, monociclo street, monociclo freestyle e monotravessia. O monociclo do tipo "girafa" e o monociclo ultimate wheel são modalidades de monociclos utilizados de acordo com o objetivo e a maturidade do praticante (BORTOLETO, LOPES, MORALES, 2008).

\section{CAPACIDADES BIOMOTORAS E METABOLISMO ENERGÉTICO DAS MODALIDADES CIRCENSES}

O "circo" ou a "atividades circenses" entendida como desporto (prática corporal) possui um conjunto de ações motoras, as quais são integrantes e específicas para a preparação do artista (ZAKHAROV, GOMES, 2003). A figura 1 demonstra que o circo possui suas modalidades de acordo com as características que contemplam o grupo dos aéreos, acrobacias, malabarismo e equilibrismo, tais grupos possuem suas modalidades. As quais foram citadas no presente estudo estão representadas em cada agrupamento respectivamente. Entre essas modalidades agrupadas encontra-se semelhanças nas ações motoras. É demonstrado também que a capacidade de força motora e o metabolismo anaeróbio são predominantes diante das características das modalidades com exceção do malabarismo e equilibrismo e, nas próprias modalidades, encontra-se as sub-divisões de força e o metabolismo anaeróbio e aeróbio 
atuando de forma específica. Diante destes apontamentos, há interação e interdependência entre estes três fenômenos.

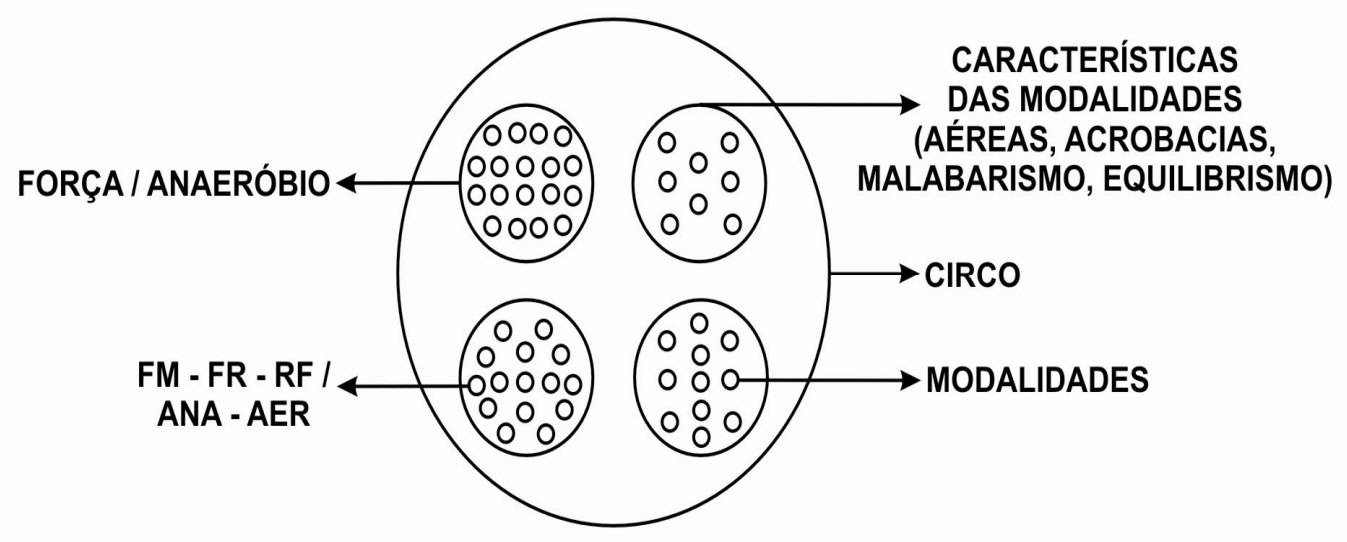

Figura 1- Inter-relação das ações motoras circenses por meio de três vertentes e, as capacidades biomotoras e as sub-divisões de força como fatores dependentes para tais atividades.

Pelos termos "capacidade" e "motora" subentende-se por uma medida de potencial das ações motoras altamente modeláveis e treináveis (BARBANTI, 2001). Gomes (2009) tem utilizado o conceito de capacidade biomotora, por unir o componente biológico ao motor dos gestos e capacidades desportivas.

Por meio destes pressupostos e relatos de Barbanti (2001), percebe-se a participação nas atividades circenses das capacidades coordenativas controladas pelos processos de condução nervosa do sistema nervoso central e determinadas pelo metabolismo energético dos músculos e sistemas orgânicos que, regulam e organizam o movimento, por isso, indispensáveis nos gestos técnicos dos movimentos esportivos. $\mathrm{O}$ autor ainda menciona que, para qualquer rendimento desportivo, é necessária a harmonia de parâmetros diferentes e envolventes em vários sistemas corporais, como sistema nervoso central, sistema cardiovascular, sistema muscular, hormonal, entre outros.

Como capacidade biomotora, a força é determinante para a realização das atividades circenses, especialmente para acrobacias e aéreos. Além disso, tem-se a relação da força com a coordenação motora e o equilíbrio para o malabarismo e equilibrismo respectivamente. De acordo com Forteza (2006), a força é uma capacidade biomotora condicionante, por depender de fatores energéticos que possibilitam a atividade neuromuscular e a transformação da energia química em mecânica para gerar movimento. Em toda modalidade esportiva esta capacidade é incluída para o condicionamento dos atletas, pois todos os movimentos humanos e posturas corporais (MARTIN, CARL, LEHNERTZ, 2008), como também para 
haver locomoção diante da força gravitacional presente no universo, é preciso trabalhar os aspectos fisiológicos para vencer esta força externa, aspectos tais representados pela tensão muscular que modulam a velocidade de execução de um movimento (BOSCO, 2007) contribuindo para as modalidades desportivas, dentre elas, o circo.

No entanto, pode-se observar que a força é expressa por duas diferentes formas de acordo com a especificidade de cada exercício e modalidade: estática ou dinâmica, ativa ou reativa. A força estática produz tensão sem movimento podendo ser encontrada principalmente nas atividades aéreas e nas poses acrobáticas onde sustentam o peso corporal pelos braços e/ou pernas permitindo a movimentação de outros segmentos corporais. Para isso, necessita de uma tensão apurada do centro do corpo (região abdominal) para equilibrar-se diante da força gravitacional e assim, realizar determinada atividade. Em contraste, a força dinâmica acontece devido a variação de comprimento do músculo por meio das fases concêntrica e excêntrica gerando movimento (BOSCO, 2007; BARBANTI, 2001), na qual execuções de acrobacias de solo e trampolim, malabarismo e equilibrismo apresentam em maior freqüência em relação à outras atividades circenses.

Por outro lado, a força pode ser ativa ou reativa. Ativa quando o movimento caracteriza um ciclo simples de trabalho muscular expressado pela combinação da força máxima dinâmica, a qual realiza com uma carga mais elevada possível sem limite de tempo apenas um movimento, com a força rápida, a qual expressa a maior força num menor tempo possível. De forma distinta, a força reativa existe quando o movimento caracteriza-se de um ciclo duplo de trabalho muscular por meio da combinação da força rápida elástica, a qual possui a fase excêntrica (alongamento) anterior a fase concêntrica (encurtamento), com a força rápida elástica reflexa que permite o movimento de amplitude reduzida e um ciclo duplo rápido devido a conseqüência de um contramovimento (ação excêntrica) (ARRUDA, HESPANHOL, 2008). A maioria dos gestos motores realizados nas atividades circenses caracteriza-se pela ação da força reativa, tendo como padrão de movimento o ciclo alongamento-encurtamento da musculatura. Em alguns casos, como o malabarismo de lançamento, verifica-se a força ativa, como fase concêntrica bem definida no exercício.

É necessário destacar que as atividades circenses expressam a força de diferentes formas em um só movimento, pois os segmentos corporais atuantes realizam trabalhos diferentes no contexto global do exercício. Porém, existe uma predominância não só do tipo de força, mas também em outras características fisiológicas. Nisto, a força é representada por três principais subdivisões:

Conexões: revista da Faculdade de Educação Física da UNICAMP, Campinas, v. 8, n. 1, p. 130-161, jan./abr. 145 2010. ISSN: $1983-930$ 
i) resistência de força,

ii) força máxima e

iii) força rápida.

Martin, Carl e Lehnertz (2008) relatam que a manifestação da capacidade de resistência de força necessita do domínio da força máxima sobre uma carga e do domínio do metabolismo da musculatura sobre a duração desta carga. Nestas circunstâncias, para realizar movimentos sequenciais em um prolongado tempo mantendo sua eficiência, é preciso superar a fadiga, assim, consegue-se resistir aos trabalhos de força que expressam a técnica condizente a cada modalidade.

Esta capacidade é relacionada às subdivisões de força, pois a partir do momento que as ações motoras de força máxima e rápida são executadas de forma contínua, ou seja, repetidas várias vezes, podem ser classificadas especificamente como força de resistência, que cujo conceito de Barbanti (2001) é realizar movimentos de força em um período longo de tempo. Este conceito deve ser considerado para as acrobacias de solo e trampolim, e malabarismo de lançamento e giroscópicos, mesmo sendo a intensidade e o tipo de movimentos diferentes.

Portanto, nas execuções de equilibrismo e malabarismo, a freqüência de impulsos nervosos são elevados devido a baixa sobrecarga (BOSCO, 2007), assim permite que o tempo de execução seja maior em relação aos aéreos e acrobacias, que por sua vez exigem elevada força de maiores grupos musculares, gastando mais energia (BARBANTI, 2001).

Em outras circunstâncias, a força máxima dinâmica recruta a maioria das unidades motoras disponíveis no músculo possibilitando um maior nível de força para superar a sobrecarga, inclusive as fibras rápidas. Por isso, não conseguem aumentar a velocidade, devido ao número de fibras rápidas indisponíveis. Com cargas menores a estas, velocidade máxima e submáxima de execução são permitidas, por meio da ativação das fibras velozes e sua quantidade. Quanto a força máxima estática, o recrutamento das unidades motoras e freqüência de estímulos são progressivos, exceto na ativação rápida, que recruta as fibras concomitantemente e a freqüência de estímulos é dada desde o início da contração (BOSCO, 2007).

Quando um grupo muscular pequeno chega próximo a $50 \%$ da contração máxima estática, outras unidades motoras são recrutadas para auxiliar na tensão. Em contraste, antes de um grupo muscular Conexões: revista da Faculdade de Educação Física da UNICAMP, Campinas, v. 8, n. 1, p. 130-161, jan./abr. 146 2010. ISSN: 1983-930 
grande atingir 80-85\% da força máxima estática, as unidades motoras recrutadas até este estágio não sentem a necessidade de ajuda, são suficientes até o exato momento (BOSCO, 2007). A tal fato, as atividades aéreas e as poses acrobáticas (modalidades tais classificadas como dependentes predominantemente da força máxima), se exemplificam nestas duas situações de tamanho de grupo muscular: na execução dos aéreos a força máxima é representada por grupos musculares menores em relação aos grupos musculares ativados na execução da acrobacia coletiva.

Da mesma forma que a força máxima, a força rápida recruta as fibras velozes e sua quantidade, a qual executa movimentos de forma mais veloz possível num curto espaço de tempo. Weineck (2003) classifica esta sub-divisão da força em capacidade neuromuscular de movimentar o corpo, parte dele e objetos em máxima velocidade e dependente da especificidade da modalidade desportiva. Esta capacidade pode ser encontrada nas modalidades acrobáticas de solo e trampolim e também no malabarismo, pois este último realiza movimentos que exigem da força rápida para manipular objetos com eficiência e precisão.

Importante destacar que a força e suas sub-divisões determinam a execução das atividades circenses como aéreos, acrobacias, malabarismo e equilibrismo. Entretanto, capacidades como coordenação motora e equilíbrio podem ser destacadas para o malabarismo e equilibrismo respectivamente. Da mesma forma, ressalta-se a flexibilidade como um fator importante para acrobacias e aéreos (GOMES, 2009).

A flexibilidade está relacionada ao desenvolvimento de outras capacidades como a força, a velocidade e a coordenação, pois a reserva de flexibilidade (possibilidade de aumento da amplitude articular), atingida com o treinamento, permite o indivíduo executar movimentos rápidos, enérgicos, fáceis e expressivos, sendo que durante os números circenses a mobilidade das articulações podem atingir 85-95\% da capacidade anatômica-esquelética (ZAKHAROV; GOMES, 2003). A flexibilidade nas atividades circenses apresenta determinância no resultado adquirido para tornar o movimento belo e eficiente. Quanto ao desenvolvimento específico desta capacidade nas acrobacias e nos aéreos é basicamente em todas as articulações, enquanto no malabarismo são ombros e punhos e no equilibrismo são tornozelos, joelhos e quadril.

Já a coordenação motora é controlada pelo sistema nervoso central e relaciona as outras quatro capacidades, além disso, ela é importante para aperfeiçoar a técnica desportiva, assegurar o indivíduo diante de situações não conhecidas e na perda de equilíbrio. Por meio desta capacidade o indivíduo consegue realizar vários exercícios complexos, todos com rapidez, precisão e eficiência (BOMPA, 2002).

Conexões: revista da Faculdade de Educação Física da UNICAMP, Campinas, v. 8, n. 1, p. 130-161, jan./abr. 147 2010. ISSN: $1983-930$ 
Além da importância desta capacidade para o quesito segurança na prática das atividades circenses, também é algo indispensável na execução para suprir a complexidade das modalidades assim como a combinação entre elas (perna de pau e malabares, rola-rola e malabares, entre outros).

Diante de tais perspectivas, apresenta-se na figura 2 as capacidades biomotoras necessárias a performance nas atividades circenses bem como as subdivisões de força motora, considerada determinante para a maioria das modalidades.

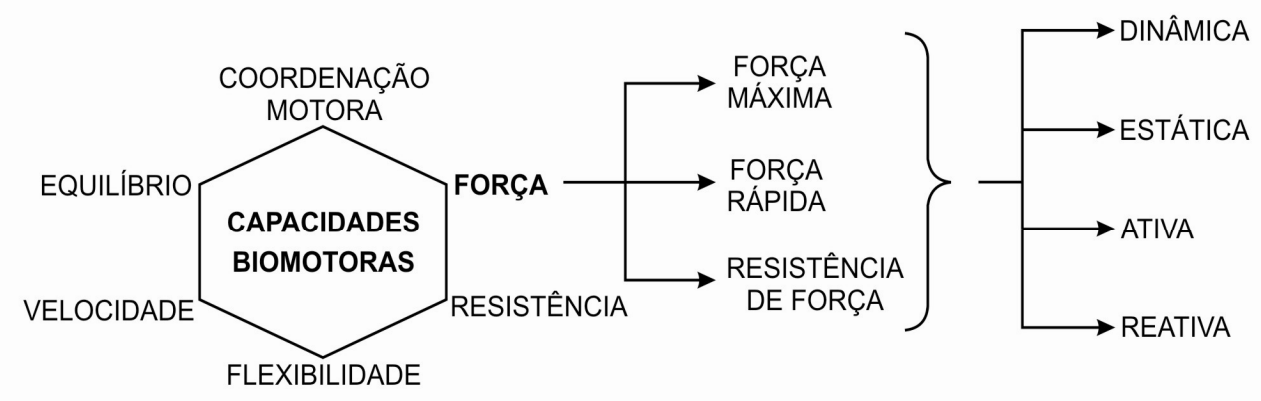

Figura 2- Capacidades biomotoras necessárias a performance nas atividades circenses.

No que concerne o metabolismo energético, Bellotto (2008) classifica as acrobacias de solo e trampolim como atividades explosivas que, necessitam de energia imediata devido a contração muscular rápida que o sistema anaeróbio alático provém. Bompa (2002) afirma que o sistema anaeróbio alático decompõe a $\mathrm{CP}$ para ressintetizar o ADP $+\mathrm{P}$ em ATP em somente 8 a 10 segundos devido a armazenação limitada na célula muscular deste substrato e, para sua reposição completa é preciso de 3 a 5 minutos ou, 30 segundos para repor $70 \%$ do estoque energético. Essa afirmação permite a classificação das acrobacias de solo e trampolim serem de metabolismo lático, pois esses números acrobáticos ultrapassam os 10 segundos e muitas vezes 60 segundos, tendo o sistema aeróbio parcialmente responsável por fornecer energia, porém a predominância é do metabolismo anaeróbio lático pela alta intensidade dos exercícios.

É importante enfatizar que numa apresentação de acrobacia de solo e trampolim, os exercícios serão executados frequentemente com corridas leves para mudança de posição e danças para compor a coreografia, enquanto isso, no organismo é feito a ressíntese parcial do substrato energético, pois segundo Bompa (2002), para recuperar o sistema anaeróbio lático é preciso de pelo menos 2 minutos, o que Conexões: revista da Faculdade de Educação Física da UNICAMP, Campinas, v. 8, n. 1, p. 130-161, jan./abr. 148 2010. ISSN: 1983-930 
$\overline{\text { depende da capacidade aeróbia, tipo de fibras, quantidade de MCT4 e MCT1 (GOMES, 2009) do }}$ organismo do indivíduo. Certo de que, se a coreografia for composta por um conjunto de séries acrobáticas que não excedam 8 a 10 segundos e, por pausas ativas de 30 segundos recuperando pelo menos $70 \%$ da CP, o sistema energético predominante será o anaeróbio alático.

No sistema aeróbio, a freqüência cardíaca e a taxa respiratória precisam aumentar para transportar a quantidade necessária de $\mathrm{O} 2$ nas células musculares para degradar o glicogênio, este é disposto pelo armazenamento nas células musculares e no fígado. A energia é gerada pela ressíntese de ADP+P no metabolismo aeróbio durante o ciclo de Krebs por meio da presença do oxigênio, o que enfatiza a extrema importância do nível de participação do oxigênio para definir a atuação dos sistemas energéticos. É fato lembrar que, haverá atuação do sistema anaeróbio e aeróbio concomitantemente, pois na aerobiose há uma pequena concentração de lactato na corrente sanguínea e graças ao $\mathrm{O} 2$ ele é oxidado e seu esqueleto carbônico é totalmente eliminado na forma de $\mathrm{CO} 2$. E na anaerobiose, há a presença do oxigênio, porém não suficiente para degradar substâncias ácidas em tempos muito curtos. A tal propósito, estudos mostram que entre 60 a 70 segundos após o início do exercício, a participação de cada metabolismo é de $50 \%$ e que, no final do primeiro minuto de um exercício intenso a participação do metabolismo aeróbio é de 47\% (KEUL; DOLL; KEPPLER, 1969; MADER; HOLLMANN, 1977 apud BOMPA, 2002). Weineck (2003) afirma que a intensidade e a duração da atividade são as responsáveis pela seleção do metabolismo energético ao utilizar o substrato condizente às necessidades metabólicas. A figura 3 apresenta uma média em relação ao suprimento de ATP por diferentes vias energéticas em seu respectivo tempo de acordo com os autores citados acima.

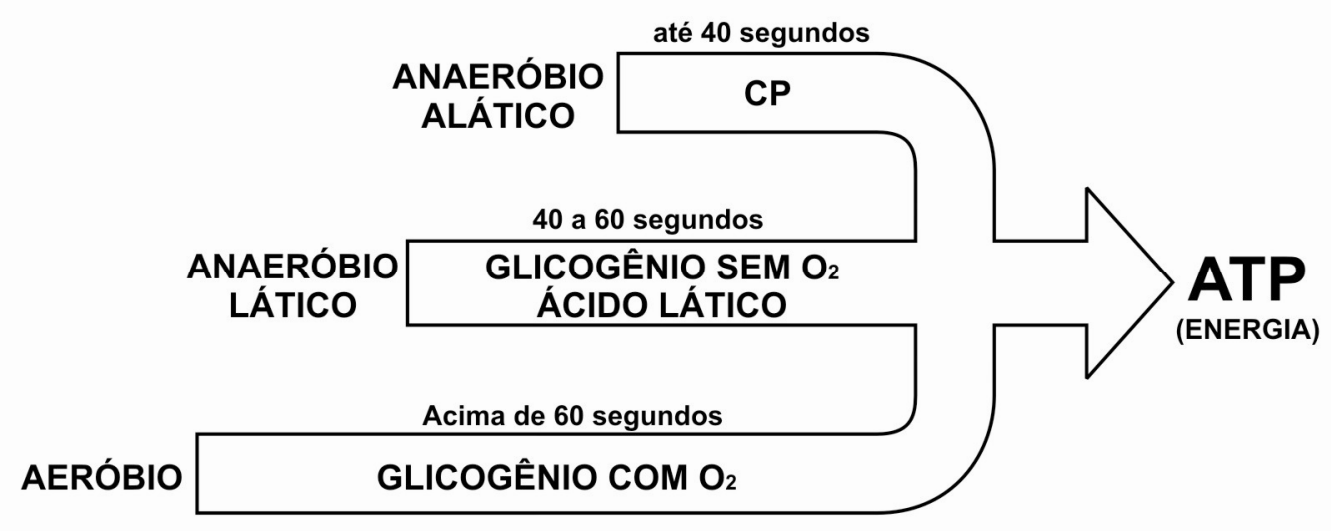

Figura 3- Suprimento de ATP por diferentes vias energéticas em seu respectivo tempo. 
$\overline{\text { Bellotto (2008) classifica os aéreos como atividades de força que não excedem } 2 \text { minutos, neste caso, } \mathrm{o}}$ sistema anaeróbio lático é atuante, enquanto a força aplicada à prática malabarística e às modalidades de equilibrismo, permite vários minutos de duração de execução na presença de oxigênio por meio do metabolismo aeróbio. A autora ainda destaca que, ao realizar as modalidades acrobacias, aéreos, malabarismo e equilibrismo por um tempo prolongado ou, vários números circenses num mesmo espetáculo, independente de sua capacidade predominante e especificidade, como acontece nas apresentações, o sistema atuante é o aeróbio.

Segundo Bortoleto e Duprat (2008), o tempo de execução de uma apresentação de paradismo (parada de mãos sob diferentes truques de membros inferiores, além das contorções, pranchas e equilíbrio) é de até 8 minutos, porém quando a modalidade é a acrobacia coletiva ou pose acrobática, o número circense pode ter o mesmo tempo de duração, mas os artistas não ultrapassam 10 segundos em cada figura executada, sempre havendo uma variação de poses. Devido a esta informação, pode-se considerar esta modalidade com predominância de metabolismo anaeróbio alático, se considerar os movimentos isolados numa apresentação que fornece energia em pouquíssimos segundos num elevado nível de força, porém será considerado o número circense como um todo tornando o metabolismo anaeróbio lático em predominância.

Considerando estas afirmações, implica a importância do desenvolvimento metabólico de resistência aeróbia determinado entre a relação das reservas energéticas disponíveis e da velocidade de consumo de energia (ARRUDA, HESPANHOL, 2008) para o treinamento e a apresentações das modalidades circenses, pois os movimentos de determinada modalidade serão executados de forma contínua numa mesma apresentação ou movimentos de diferentes modalidades num mesmo espetáculo. Este tipo de resistência garante a capacidade de recuperação dos substratos durante os intervalos de treinos (micropausa e macropausa) diante de trabalhos extremos (FORTEZA, 2006), como é o caso das modalidades circenses.

Neste sentido, a resistência de força é dependente do metabolismo aeróbio e anaeróbio, o primeiro permite que o atleta trabalhe em intensidade alta em menor concentração de ácido lático e assim, aumentar a energia total disponível, auxiliando na recuperação (BOMPA, 2002). O outro, auxilia na manutenção da força durante a execução, já que os diversos sistemas tamponentes (bicarbonato, fosfato, plasma, etc) irão impedir uma alteração drástica intracelular, fazendo com que as enzimas continuem atuando na mesma velocidade mantendo o fornecimento de energia.

Conexões: revista da Faculdade de Educação Física da UNICAMP, Campinas, v. 8, n. 1, p. 130-161, jan./abr. 150 2010. ISSN: $1983-930$ 
Ademais, foi proposta na tabela 3 uma classificação conforme predominância do tipo de contração muscular, capacidades biomotoras e via energética dos gestos motores de modalidades circenses semelhantes. Foi preciso separar a acrobacia coletiva das outras devido ao tipo de força distinto comparado às outras acrobacias.

Tabela 3- Classificação conforme predominância do tipo de contração muscular, capacidades biomotoras e via energética do agrupamento e/ou modalidades circense da mesma característica e de gestos motores semelhantes.

\begin{tabular}{cccc}
\hline $\begin{array}{c}\text { Modalidades circenses e grupo de } \\
\text { modalidades } \\
\text { de características semelhantes }\end{array}$ & $\begin{array}{c}\text { Tipo de } \\
\text { contração } \\
\text { muscular }\end{array}$ & $\begin{array}{c}\text { Capacidades } \\
\text { biomotoras }\end{array}$ & $\begin{array}{c}\text { Via energética/ } \\
\text { Metabolismo }\end{array}$ \\
\hline Acrobacias de solo e trampolim & Dinâmica/Reativa & Força rápida & $\begin{array}{c}\text { Anaeróbio } \\
\text { lático } \\
\text { Anaeróbio } \\
\text { lático } \\
\text { Acrobacias coletiva/poses acrobáticas }\end{array}$ \\
Atividades aéreas & Estática & Força máxima & lático \\
Malabarismo & Estática & $\begin{array}{c}\text { Força máxima } \\
\text { Resistência de } \\
\text { força }\end{array}$ & Aeróbio \\
Equilibrismo & Dinâmica/Ativa & $\begin{array}{c}\text { Resistência de } \\
\text { força }\end{array}$ & Aeróbio \\
\hline
\end{tabular}

\section{EXERCÍCIOS COMO MEIO DE TREINAMENTO DAS ATIVIDADES CIRCENSES}

Martin, Carl e Lehnertz (2008) afirmam que o treinamento ocorre em diversas áreas de atuação, inclusive para atividades não competitivas, como é o caso das atividades circenses, na intenção de influenciar sistematicamente o desempenho a ser desenvolvido, a apresentação e o sucesso dos mesmos, sempre considerando a individualidade biológica.

Conexões: revista da Faculdade de Educação Física da UNICAMP, Campinas, v. 8, n. 1, p. 130-161, jan./abr. 151 2010. ISSN: $1983-930$ 
Foi visto que a capacidade de força é determinante entre as diferentes modalidades circenses e em alguns casos como no grupo de modalidade de características aérea e acrobática, esta capacidade é predominante. Para que ela se manifeste eficientemente no momento das apresentações é necessário um suporte de treinamento. Além da metodologia, os exercícios ou meios de treinamento são necessários para atingir determinado objetivo independente do tipo da modalidade. Eles caminham juntos em busca de um determinado objetivo de preparação. Existem duas direções de se trabalhar a capacidade de força: de forma geral ou especial. Barbanti (2001) relata que o treinamento geral de força é necessário para desenvolver a musculatura de todo o corpo do praticante, não somente aquela porção que é utilizada no gesto motor específico da modalidade. De forma contrária, o treinamento especial de força trabalha exercícios parecidos com o gesto motor executado durante a ação esperada, ou seja, são imitações parciais que fortalecem os mesmos músculos realizados durante o ato esperado e da importância deste trabalho, por ser próximo do padrão esportivo, pois a força é específica para cada modalidade.

O exercício físico é o meio principal na preparação do desportista no sentido de utilizar as ações motoras adequadas ao tipo da prática esportiva, como no caso das atividades circenses. Eles podem ser apresentados em exercício competitivo, o qual objetiva resultados máximos simulando as condições reais das competições, como seqüência de apresentações, seqüência de exercícios, aquecimento, alimentação, música, local, aparelho, temperatura ambiente, vestimenta, entre outros; exercício preparatório especial, o qual corresponde a treinabilidade dos principais exercícios que determinam o exercício preparatório competitivo; e preparatório geral, o qual potencializa o desenvolvimento natural do organismo reforçando o que é determinante na modalidade esportiva (ZAKHAROV, GOMES, 2003).

No sentido de exemplificar a importância dos exercícios físicos, a tabela 4 apresenta uma sessão de treino circense com o objetivo de atingir melhora nos exercícios de trapézio fixo, como figuras e quedas, assim como adquirir resistência específica para determinada tarefa e conseqüentemente para outras modalidades circenses que contenham os gestos esportivos semelhantes a estes. 
Tabela 4- Exemplo de uma sessão de treinamento voltada ao desenvolvimento da resistência específica para trapézio fixo.

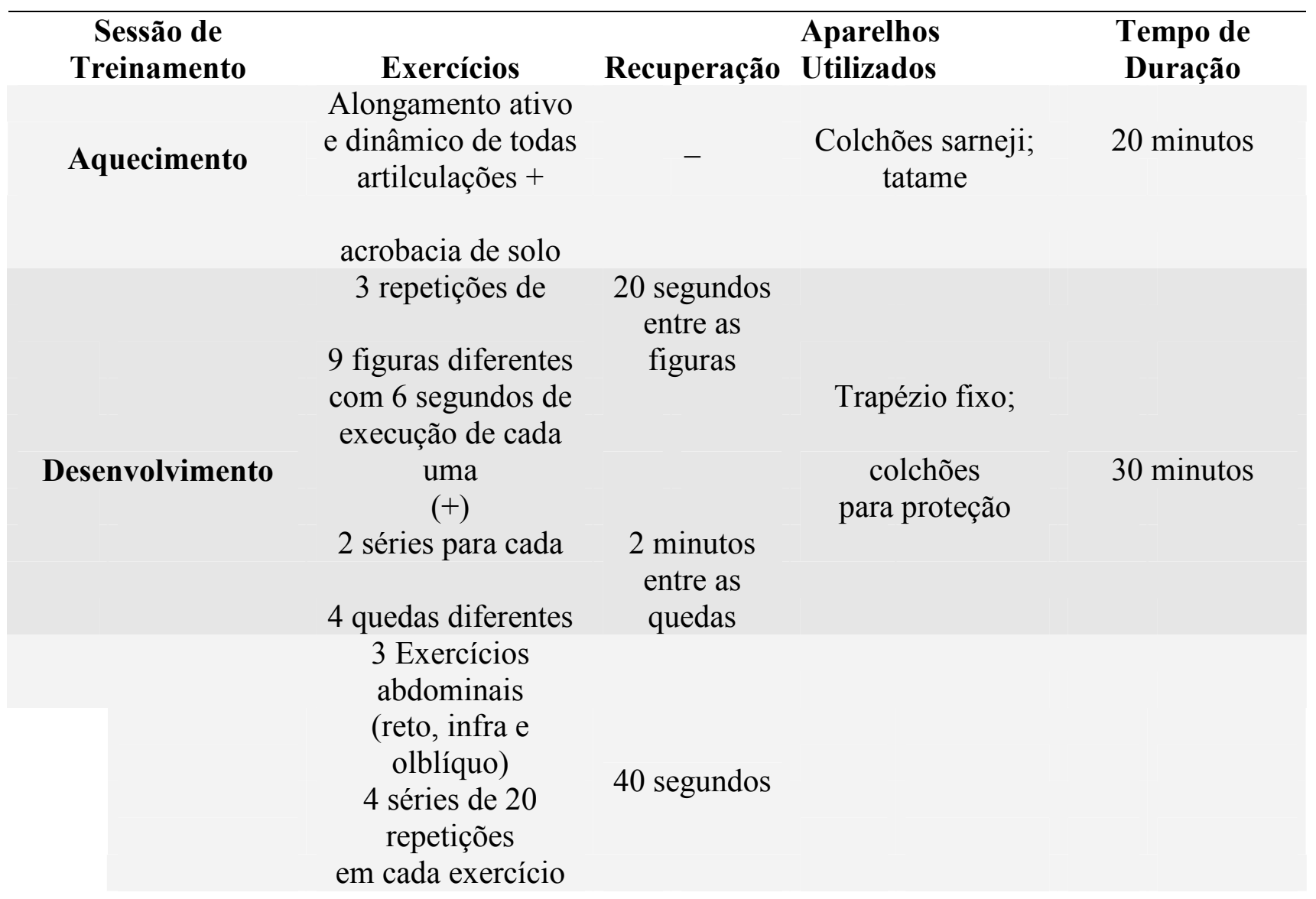


Volta à calma
$(+)$

Alongamento

passivo de

membros inferiores

e

ativo de membros

superiores e tronco
Colchões ou

tatame
10 minutos

A acrobacia de solo pode ser adotada como parte da preparação geral dos artistas circenses e como aquecimento das sessões diante de todas as modalidades, pois para sua execução vários grupos musculares e segmentos corporais estarão atuando. Por meio de suas evoluções acrobáticas, o controle e domínio corporal são explorados, dando subsídios para outras modalidades circenses. Em sua maioria, os praticantes de acrobacias têm mais habilidade em executar outras modalidades do que os que não praticam.

O desenvolvimento desta sessão de treino é feito por figuras e quedas possíveis em realizar no trapézio fixo, tais exercícios serão determinados de acordo com o nível de aptidão de cada indivíduo bem como da turma. Por considerar atletas circenses de nível médio, optou-se de forma regressiva em relação a intensidade e dificuldade, pois exercícios de alta complexidade exigem mais energia e concentração no momento da execução, onde o início do esforço supre esta demanda devido aos estoques energéticos mais elevados em comparação ao final do desenvolvimento da sessão de treino. Como exemplo de seqüência das figuras pode-se considerar: pose de rim, cristo invertido, plunch na corda, cama, cristo, banana com giro, single knee hang, splits, bird's nest; e de quedas: queda do anjo, queda do pé saindo da posição sentada, queda do pike e um giro e meio em volta da barra. Esta ordem de exercícios deve-se a explicação de Weineck (2003): no início da atividade adquire-se condições para contração forte e rápida.

Para otimizar o trabalho final, ou seja, a condição biomotora desejada, é possível aplicar exercícios preparatórios gerais e localizados (aqueles que trabalham menos de 1/7 da musculatura total do corpo humano). Com essas condições, é aconselhável treinar os segmentos corporais consideravelmente decisivos para os exercícios circenses na fase final da sessão. A região core (região central do corpo) é uma das mais importantes, seguida de membros superiores, devido a utilização freqüente destes seguimentos corporais, principalmente entre os exercícios das modalidades aéreas e acrobáticas, sendo que o equilibrismo utiliza principalmente os membros inferiores e a região core para suas realizações, enquanto no malabarismo supera-se a resistência de força de membros superiores para manipular os 
$\overline{\text { objetos, os membros inferiores para mudança ou manutenção da posição e a região core paradar }}$ sustentação aos movimentos. Por isso, exercícios localizados como abdominais, extensão de tronco, e flexão de braços seriam uma ótima opção, assim como exercícios funcionais para complementar esta fase do treino.

Antes do término da sessão é necessário aproximar-se fisiologicamente às condições iniciais da mesma por meio de alongamentos. Neste momento, é importante destacar para a dissociação entre flexibilidade e alongamento para não haver desagradáveis situações de desconforto para o atleta prejudicando o seu rendimento. É preciso atentar com a forma e o momento de trabalhar os meios respeitando a metodologia e periodização estruturada, para que não deprecie as capacidades biomotoras e assim, não prejudique a performance das apresentações e dos treinamentos.

A tal propósito, Barbanti (2001) menciona que o desenvolvimento de uma capacidade biomotora acarretará a influência positiva ou negativa em outras capacidades, que dependerá da treinabilidade do indivíduo e da sobrecarga utilizada na realização dos exercícios. De qualquer forma essa influência existe, devido a ação paralela das capacidades, principalmente pelos efeitos concorrentes do treinamento aumentando a importância do controle das cargas de treino.

Nisto, possibilita atribuir às atividades circenses outras práticas na intenção de somar os meios de treinamento dessas atividades. O treinamento funcional pode auxiliar no período de trabalho da força especial, pois é desenvolvido para trabalhar a funcionalidade dos movimentos específicos para cada indivíduo em relação à sua atividade no sentido de atingir a melhor performance e também, como exercícios preparatórios gerais, pois o indivíduo treinado poderá adquirir as capacidades biomotoras de equilíbrio, força, velocidade, coordenação, flexibilidade e resistência de maneira simultânea, por meio de movimentos, tornando a atividade dinâmica e abrangendo novas experiências ao indivíduo a cada sessão de treino (D'ELIA, 2008).

Por meio de relatos de Weineck (2003), o programa de treinamento deve ser específico quando o movimento também for, e por isso diferenciado, porém quando houver semelhanças na ação motora o treino deve ser o mesmo.

Pelo dinamismo dos movimentos que aumentam o repertório motor dos indivíduos e por alguns materiais utilizados como bolas e superfícies instáveis encontrados semelhantemente entre as modalidades circenses e o treinamento funcional, permite um auxílio mútuo entre elas: o treinamento funcional pode Conexões: revista da Faculdade de Educação Física da UNICAMP, Campinas, v. 8, n. 1, p. 130-161, jan./abr. 155 2010. ISSN: 1983-930 
contribuir para a melhor performance da prática circense por meio da especialização e generalização das capacidades e habilidades treinadas, por outro lado, a prática circense pode ser adotada como forma de preparo físico em outras modalidades esportivas e também como meio para objetivar a saúde e qualidade de vida dos indivíduos. É fato destacar que nem todas as modalidades circenses são viáveis treinar movimentos paralelos na intenção de melhorar determinada habilidade, neste caso, o indicado é a repetição do próprio movimento.

Diante de qualquer classificação de exercícios físicos, seja ele preparatório especial, preparatório geral ou competitivo, deve-se sempre buscar a supercompensação na estruturação do treinamento desportivo, por meio da intensidade adequada, assim restaura-se a energia, evita-se níveis críticos de fadiga, assegurando um resultado desejável ao treinamento (BOMPA, 2002). Frente a estes apontamentos, é necessário atentar-se que a prescrição de meios de treinamentos voltados às modalidades circenses depende de fatores como:

i) momento da preparação para as apresentações,

ii) tempo disponível,

iii) objetivos a serem alcançados, bem como

iv) as características morfofuncionais, maturacionais e nível competitivo dos atletas circenses.

\section{CONSIDERAÇÕES FINAIS}

Destacou-se no presente estudo que a atividade circense, circo ou arte circense, pode ser considerada um desporto com diferentes direcionamentos, para o lazer-recreação, o alto rendimento ou a educação. Esta arte possui variadas modalidades, nas quais os artistas executam movimentos técnicos e usam de sua criatividade para inventar novos movimentos no sentido de encantar o público e inevitavelmente o próprio praticante.

O circo novo é influenciado por indivíduos de diferentes conhecimentos, tanto prático quanto cênico, artístico e físico, se diferenciando do circo moderno por ser desenvolvido por famílias tradicionais circenses, o que não deixa de possuir características práticas, cênicas, artísticas e físicas, porém de forma empírica. De qualquer maneira, o circo objetiva surpreender o público sem regras a ser cumpridas e a julgamentos que decidem seu status diante de federações como acontece nos esportes de alto rendimento.

O presente estudo analisou principalmente a capacidade biomotora de força e suas sub-divisões. A partir disso, percebeu-se que esta capacidade encontra-se presente e determinante para a execução das Conexões: revista da Faculdade de Educação Física da UNICAMP, Campinas, v. 8, n. 1, p. 130-161, jan./abr. 156 2010. ISSN: $1983-930$ 
$\overline{\text { atividades circenses, mesmo não sendo esta a capacidade predominante, como é o caso do malabarismo } \mathrm{e}}$ equilibrismo que, encontra-se outras capacidades biomotoras predominantes para se expressarem de tal forma, como a coordenação motora e o equilíbrio respectivamente. Porém, é fato destacar que, as outras modalidades dos grupos de acrobacia e aéreos onde a capacidade de força predomina, também existe a participação de outras para os movimentos serem realizados com eficiência, como a resistência, a velocidade e suas sub-divisões que poderão ser analisadas especificamente em outros estudos. Por este motivo, não devem ser desconsiderados os princípios de treinamento para se desenvolver as capacidades envolventes com os exercícios propostos por cada modalidade circense.

Nas modalidades de acrobacias de solo e trampolinismo, a força rápida predomina gerando energia por meio do metabolismo anaeróbio lático devido a movimentos velozes utilizando a força em um curto espaço de tempo, porém, em repetidas vezes. Enquanto a acrobacia coletiva e as modalidades do grupo aéreos utilizam em maior instância, da força máxima para suas evoluções, dependendo do metabolismo anaeróbio lático devido a alta intensidade aplicada repetidas vezes na realização dos movimentos em um número circense destas modalidades, o malabarismo e o equilibrismo são atividades que utilizam da resistência de força gerando energia por meio do metabolismo aeróbio devido a baixa carga que permite um tempo longo de execução. Portanto o metabolismo anaeróbio predomina entre as modalidades circenses, de forma que deve atentar-se para a sessão de treino dessas atividades utilizando os princípios fisiológicos para aplicar tais atividades com eficiência e segurança aos praticantes.

A resistência de força é a capacidade biomotora indispensável às modalidades, pois nos treinamentos assim como nos espetáculos, os exercícios são realizados constantemente necessitando da capacidade aeróbia para manter os níveis energéticos gerando precisão e eficiência às execuções dos atletas. Desta forma, os exercícios preparatório geral, especial e competitivo contribuem para uma efetiva sessão de treino, desde que organizados de acordo com a fase da periodização.

A revisão de bibliografia realizada permite levantar indicadores para futuros estudos experimentais, os quais poderão obter dados objetivos e que talvez permitam interferências científicas sobre quais capacidades biomotoras se destacam em cada uma das diferentes modalidades circenses. Porém, tornamse importante estes direcionamentos já que é vasto a pesquisa na área do circo, principalmente no aspecto biológico que encontra-se necessitado de interesse científico no sentido de melhorar a performance dos atletas e artistas circenses.

Conexões: revista da Faculdade de Educação Física da UNICAMP, Campinas, v. 8, n. 1, p. 130-161, jan./abr. 157 2010. ISSN: 1983-930 
A partir disso, sugere-se em futuros estudos atentar-se para

i) periodização das atividades circenses,

ii) atividades circenses como meio para o treinamento funcional,

iii) alimentação adequada para atletas circenses de acordo com determinada modalidade,

iv) exercícios preparatórios especiais para alta performance em determinado movimento e/ou modalidade circense, v) a eficiência de exercícios propostos ao resultar em determinado movimento e vi) analisar outros agrupamentos de modalidades circenses, do mesmo modo deste estudo.

\section{REFERÊNCIAS}

ALVES, S. C. C. et al. Intervenção e conhecimento em performance humana: atividade física no âmbito do treinamento desportivo e da saúde. In MOREIRA, W. W.; SIMÕES, R. Educação física: intervenção e conhecimento científico. Piracicaba: UNIMEP, 2004. 282 p.

ARRUDA, M.; HESPANHOL, J. E. Saltos verticais. São Paulo: Phorte, 2008. 136 p.

BARBANTI, V. J. Treinamento fisico: bases científicas. 3. ed. São Paulo: CLR Balieiro, 2001. p. 116.

BARONI, J. R. Arte circense: a magia e o encantamento dentro e fora das lonas. Revista Pensar a Prática, v. 9 , n.1, p. 81-99, 2006.

BELLOTTO, M. L. Nutrição e circo: aspectos complementares. In BORTOLETO, M. A. C. Introdução à pedagogia das atividades circenses. Jundiaí: Fontoura, 2008. 272 p.

BOMPA, T. O. Periodização: teoria e metodologia do treinamento. 4. ed. São Paulo: Phorte, 2002. 423 p. 
BORTOLETO, M. A. C. A perna de pau circense. Revista Motriz Rio Claro, v. 9, n. 3, p.125-133, $2003 \mathrm{~b}$. - Atividades circenses na ginástica geral: Brasil e Espanha. In: II Fórum Internacional de Ginástica, SESC, Campinas, p.1-15, 2003a.

. Acrobacia de solo. In BORTOLETO, M. A. C. Introdução à pedagogia das atividades circenses. Jundiaí: Fontoura, 2008a. 272 p.

. Circo y educación física: los juegos circenses como recurso pedagógico. Revista Stadium, n. 195, 2006.

. O caráter objetivo e o subjetivo da ginástica artística. Dissertação-(Mestrado)- Faculdade de Educação Física, Universidade Estadual de Campinas, Campinas, 2000.

. Perna de pau. In BORTOLETO, M. A. C. Introdução à pedagogia das atividades circenses. Jundiaí: Fontoura, 2008b. 272 p.

. Rola-rola. In BORTOLETO, M. A. C. Introdução à pedagogia das atividades circenses. Jundiaí: Fontoura, 2008c. 272 p.

. Rola-bola: iniciação. Revista Movimento \& Percepção, v.4, n.4/5, p.100-109, 2004.

; CALÇA, D. H. Circo e educação física: compendium das modalidades aéreas. Revista Movimento \& Percepção, v. 8, n.11, p.345-360, 2007c.

.; CALÇA, D. H. O tecido circense: fundamentos para uma pedagogia das atividades circenses aéreas. Revista Conexões, v. 5, n.2, p.73-89, 2007a.

.; CALÇA, D. H. O trapézio circense: estudo das diferentes modalidades. Revista Digital Ef. Deportes.com, ano 12, n.109, 2007b.

BORTOleto, M. A. C.; DUPRAT, R. M. Parada de mãos. In BORTOlETO, M. A. C. Introdução à pedagogia das atividades circenses. Jundiaí: Fontoura, 2008. 272 p.

.; ESCALANTE, O. Acrobacia circense: el flic-flac adelante. Revista Ambidextro, n. 40, p.17-20, 2006b.

.; ESCALANTE, O. El salto mortal adelante. Revista Ambidextro, n.41, 2006a.

.; LOPES, D. C.; MORALES, D. A. Monociclo. In BORTOLETO, M. A. C. Introdução à pedagogia das atividades circenses. Jundiaí: Fontoura, 2008. 272 p.

.; MACHADO, G. A. Reflexões sobre o Circo e a Educação Física. Revista Corpoconsciência, n.12, p.39-69, 2003.

BOSCO, C. A força muscular: aspectos fisiológicos e aplicações práticas. São Paulo: Phorte, 2007. 504 p. CALÇA, D. H.; BORTOLETO, M. A. C. Tecido. In BORTOLETO, M. A. C. Introdução à pedagogia das atividades circenses. Jundiaí: Fontoura, 2008. 272 p.

Conexões: revista da Faculdade de Educação Física da UNICAMP, Campinas, v. 8, n. 1, p. 130-161, jan./abr. 159 2010. ISSN: 1983-930 
D’ELIA, L. Treinamento funcional. Revista Informe Phorte, ano 12, n. 24, 2008-2009.

DE GÁSPARI, J. C.; SCHWARTZ, G. M. Vivência em artes circenses: motivos de aderência e expectativas. Revista Motriz Rio Claro, v. 13, n. 3, p. 158-164, 2007.

DICIONÁRIO PRIBERAM DA LÍNGUA PORTUGUESA, 2009. Disponível em: http://www.priberam.pt/DLPO/. Acesso em: 10 ago 2009.

DUPRAT, R. M. Atividades circenses: possibilidades e perspectivas para a educação física escolar. Dissertação (Mestrado)- Faculdade de Educação Física, Universidades Estadual de Campinas, Campinas, 2007.

DUPRAT, R. M.; BORTOLETO, M. A. C. Educação Física escolar: pedagogia e didática das atividades circenses. Revista Brasileira de Ciências do Esporte, v. 28, n. 2, p. 171-190, 2007.

. Malabares: bolas. In BORTOLETO, M. A. C. Introdução à pedagogia das atividades circenses. Jundiaí: Fontoura, 2008. 272 p.

FORTEZA, R. A. Direções de treinamento: novas concepções metodológicas. Rio de Janeiro: Phorte, 2006. 231 p. GALLARDO, J. P.; GUITIÉRREZ, L. L. As relações do circo com a escola. In BORTOLETO, M. A. Introdução à pedagogia das atividades circenses. Jundiaí: Fontoura, 2008. 272 p.

GOMES, A.C. Treinamento desportivo: estruturação e periodização. 2. ed. Porto Alegre: Artmed, 2009. $276 \mathrm{p}$.

MANSUR, M., et al. Influencia do malabarismo na aprendizagem, resposta ao estimulo visual e memória de idosos. Revista Mackenzie de Educação Física e Esporte, v. 6, n. 3, p. 87-92, 2007.

MARTIN, D.; CARL, K.; LEHNERTZ, K. Manual de teoria do treinamento esportivo. São Paulo: Phorte, 2008. $452 \mathrm{p}$.

PELEGRINOTTI, I. L. Performance humana: saúde e esporte. Ribeirão Preto: Tecmedd, 2004. 356 p.

REGO, F., REIS, M., OLIVEIRA, R. Lesões em ginastas portugueses de competição das modalidades de trampolins, ginástica acrobática, ginástica artística e ginástica rítmica na época 2005/2006. Revista Portuguesa de Fisioterapia no Desporto, v. 1, n. 2, p. 21-27, 2007.

SILVA, E. O circo: sua arte e seus saberes, o circo no Brasil do final do século XIX a meados do XX. Dissertação(Mestrado)- Instituto de Filosofia e Ciências Humanas, Universidade Estadual de Campinas, Campinas, 1996.

SILVEIRA, J. F. B.; SILVA, M. R. S.; CASTRO, D. L. O mundo mágico do circo: o saber incorporado e compartilhado. In: Anais do IV Congresso Sulbrasileiro de Ciências do Esporte, Faxinal do Céu, p. $272-$ 282, 2008.

THOMAS, J. R.; NELSON, J. K.; SILVERMAN, S. J. Métodos de pesquisa em atividade fisica. 5. ed. Porto Alegre: Artmed, 2007. p. 396.

Conexões: revista da Faculdade de Educação Física da UNICAMP, Campinas, v. 8, n. 1, p. 130-161, jan./abr. 160 2010. ISSN: 1983-930 
TOMAZ, F. E.; MOTTA, L. M.; SOUZA, D. G. Análise comparativa de parâmetros hemodinâmicos $e$ antropométricos entre escaladores indoor e de tecido. In: VI Congresso Internacional de Educação Física e Motricidade Humana. Rio Claro. Revista Motriz, v. 15. p. 186, 2009.

TORRES, A. O Circo no Brasil. Rio de Janeiro: Funarte, São Paulo: Atração Produções Ilimitadas, 1998. p. 338.

ZAKHAROV, A.; GOMES, A. C. Ciência do treinamento desportivo. Rio de Janeiro: Grupo Palestra Sport, 2003.330 p.

WEINECK, J. Treinamento ideal: instruções técnicas sobre o desempenho fisiológico, incluindo considerações específicas de treinamento infantil e juvenil. 9. ed. São Paulo: Manole, 2003. 740 p. 
RAQUEL DE BRITO SACCO

Universidade Metodista de Piracicaba/UNIMEP

Faculdade de Educação Física

e-mail: raquelbsacco@hotmail.com

Telefones para contato: (19) 9238-1390 ou (19) 3702-5628

\section{Tiago Volpi Braz}

Laboratório de Avaliação Física e Monitoramento do Treinamento Desportivo (LAFIMT)

Universidade Metodista de Piracicaba- Campus Taquaral

e-mail: tiagovolpi@yahoo.com.br

Rodovia do Açúcar, KM 156 - CEP: 13.400-911

Piracicaba - SP

\section{Referência do artigo}

\section{ABNT}

SACCO, R. B.; BRAZ, T. V. Atividades circenses: caracterização das modalidades, capacidades biomotoras, metabolismo energético e implicações práticas. Conexões, v. 8, n. 1, p. 130162.

\section{APA}

Sacco, R. B., \& Braz, T. V. (2010). Atividades circenses: caracterização das modalidades, capacidades biomotoras, metabolismo energético e implicações práticas. Conexões, 8(1), 130-162.

\section{VANCOUVER}

Sacco, RB., BRAZ, TV. Atividades circenses: caracterização das modalidades, capacidades biomotoras, metabolismo energético e implicações práticas. Conexões, 2010; 8(1): 130-162.

Recebido em: 04/11/2009

Aceito para publicação em: mar. 2010 